\title{
SOCIAL ASSESSMENT OF THE NEIGHBOURHOOD SERVICES IN THE URBAN AREA ŻYDOWCE IN SZCZECIN (POLAND)
}

\author{
NATALIA SYPION-DUTKOWSKA, ${ }^{1}$ MAŁGORZATA KARWAN ${ }^{2}$ \\ University of Szczecin, Faculty of Geosciences, POLAND \\ ${ }^{1}$ e-mail: natalia.sypion@usz.edu.pl \\ ${ }^{2}$ e-mail: malgorzata.karwan.us@wp.pl
}

RECEIVED
ACCEPTED
JEL
CLASSIFICATION

KEYWORDS

ABSTRACT
10 December 2018

28 December 2018

$\mathrm{H} 4, \mathrm{P} 36, \mathrm{R} 23$

services, neighbourhood services, social assessment, urban area

Satisfying social needs with an appropriate level of services is an important element of the quality of life in every settlement (village, urban district, neighbourhood). The neighbourhood services satisfy the basic everyday needs of the residents of a given residential area, which is covered by their range of influence. One of the methods used to assess the social assessment of this type of services is the direct interview. Based on the conducted direct surveys the level and quality of offered neighbourhood services, requiring improvement of them, and missing services in the urban area Żydowce in Szczecin were identified.

\section{Introduction}

Services are economic activities aimed at satisfying individual and collective needs, and no material goods transfer. They can be classified by to the criterion of their character, impact range, frequency of use, hierarchy, location and sources of financing. The most important classifications of service activities are: the United Nations' International Standard Industrial Classification (ISIC), the Statistical Classification of Economic Activities 
in the European Community (NACE), and similar national systems in other countries, like in Poland - Polska Klasyfikacja Wyrobów i Usług (PKWiU). Services can be provided at the international, national, regional, local, family, and individual level.

In the modern economy services are the most important sector, called the tertiary sector, supplying the majority of GDP and employing the majority of employees. Some of these service activities are specialized and support relatively small but efficient first (mining, agriculture, fisheries) and the second (industry) sector. They occur mainly in highly developed countries.

A special place among service activities, however, occupy those that serve the existential, basic and everyday needs of people living in a specific area. These service activities are called local or neighbourhood services. These types of services, although of different quality and not always in full range, are also found in the medium and low developed countries, creating numerous jobs. Because they require daily access, and the time spent to reach their place of distribution is limited, their location is determined by the distribution of residents. This is the effect of market forces as well as planned activities of local authorities. Some of these services are public and free. As a rule, they include (in medium and highly developed countries): nursery, kindergarten, primary and secondary school, health center, pharmacy, grocery store, butcher shop, bakery, dairy shop (or supermarket), tailor, shoemaker, beautician, hairdresser, pub, fast food restaurant, news stand, post office, Internet café. Forced or voluntary use of services determines the distribution of types of service facilities to the recipient. A necessary condition for the use of the offer is the spatial availability of services, especially at the local level. Improper placement of optional service facilities affects the profitability of enterprises, while difficult access to obligatory services causes numerous social problems (Barton, Grant, Guise, 2006).

The purpose of the presented research was to obtain a social assessment regarding the neighbourhood services located in the urban area Żydowce. The following research questions were posed:

1. How do the residents of the urban area Żydowce assess the quality of offered neighbourhood services?

2. How do they assess the level of offered neighbourhood services in the urban area Żydowce?

3. Which neighbourhood services, according to the respondents, need improvement?

4. What neighbourhood services are missing in this urban area?

The research questions posed in this way allowed the following hypotheses to be adopted:

a) there is not enough neighbourhood services offered in the urban area Żydowce to meet the needs of their residents;

b) the quality of offered neighbourhood services in the urban area Żydowce is at a poor level;

c) among the neighbourhood services requiring immediate improvement, existing catering and gastronomy services as well as public transport can be distinguished;

d) neighbourhood services currently lacking in the urban area Żydowce are medical care, pharmacies, entertainment and advanced catering and food supply services.

\section{Literature review}

The term "services" has many different definitions. American Marketing Association (2018) dictionary defines services doubly "firstly services as a products (e.g., as a bank loan or home security), that are intangible or at least substantially so. If totally intangible, they are exchanged directly from producer to user, cannot be transported or stored, and are almost instantly perishable. Service products are often difficult to identify, because they come into 
existence at the same time they are bought and consumed. They comprise intangible elements that are inseparable; they usually involve customer participation in some important way; they cannot be sold in the sense of ownership transfer; and they have no title. Today, however, most products are partly tangible and partly intangible, and the dominant form is used to classify them as either goods or services (all are products). These common, hybrid forms, whatever they are called, may or may not have the attributes just given for totally intangible services. Secondly, services are also used to describe activities performed by sellers and others that accompany the sale of a product and aid in its exchange or its utilization (e.g., shoe fitting, financing). Such services are either presale or post-sale and supplement the product, not comprise it. If performed during sale, they are considered to be intangible parts of the product."

A. Payne (1997, p. 20) defines a service as any activity containing an element of intangibility, which consists in influencing the client or objects or property in his possession, and which does not transfer ownership. J. Chmielewski (2001, p. 176) believes that services are the third sector of human economic activity. The goal is to meet social, material and non-material needs that are constantly growing. They can be performed at the level of family life, by one citizen for the other and by public institutions. K. Kłosiński (2011) claims that services are activities whose effect is to satisfy specific needs of an entity, which may be a person, enterprise, commune, city or country. D. Innicki (as cited in Nowosielska, 1994, p. 30) defines services as all service works (activities) irrespective of their place in the classification of the national economy, i.e. both services classified in the production sectors of the economy (in agriculture and forestry, and industry and construction) as well as work done in service departments (i.e. not being agricultural, industrial, etc.). P. Kotler (as cited in Hollins, Shinkins, 2006, p. 8) determines service as any act or benefit that can be given to someone else and is immaterial and has no effect on the ownership of anything. Its production may or may not be related to a physical product.

Large variety of services results from different features of their location and demand. Therefore, services can differentiated between various divisions of service classification. E. Lipiński (as cited in Rogoziński, 1993, p. 65) distinguished three types of services:

1. Service for the buyer - it includes the buying and selling acts, transport, packaging, repairs and repairs of devices intended for satisfying consumption needs as well as for production purposes.

2. Personal service - this includes services that go beyond the field of elementary needs. They cover higher needs and corresponding ways of satisfying in the form of communication services and eating meals in a restaurant.

3. Personality support - it includes services satisfying higher-order needs. These are entertainment services, education, tourism and other forms of cultural "consumption".

E. Jakubowicz (1993) proposed a detailed multicriteria classification of the service activities:

a) the time of the appearance of the service effect can be distinguished here:

- services whose effect is revealed after a very short time; they can also contribute to the creation of an additional work force,

- services, the effect of which appears after an average period of time,

- services, the effect of which is revealed after a long time;

b) the size of the area covered by the action:

- basic or local services, occurring in the village, housing estate, neighbourhood or urban unit in the city, e.g. small shops with basic articles or kindergartens, 
- higher-level or post-basic services, occurring in village groups, small towns, districts of large cities, regions and over regions;

c) the period of service provision:

- permanent services,

- services provided for a certain period of time;

d) the exactness of the relationship with the given area:

- services closely related to a given area due to conditions or size,

- services related to the country's zonation due to supply,

- services with a free location;

e) social environment:

- services covered by the existing situation,

- services covered by the existence of the environment and capable of creating the environment,

- services strictly requiring a specific social environment;

f) remuneration for services:

- paid services,

- non-payable services;

g) distribution method:

- market services,

- non-market services,

h) the specificity of needs:

- services for the village or the neighbourhood,

- services for cities, services for adults,

- youth services;

i) leisure time management, i.e. services that fill free time;

j) civilization level:

- fixed, their number decreases along with economic development,

- new, their development takes place with increasing consumption,

- complementary.

According to the above presented proposal of E. Jakubowicz (1993), neighbourhood services have the some specific features. They are:

- basic or local services, occurring closely related to a small residential area,

- services whose effect is revealed after a very short time,

- services contributing to the creation of local work places,

- permanent services, sometimes offered around the clock,

- services covered by the existing situation,

- services both paid and market (shop) and non-payable and non-market (public school),

- fixed services, and their number decreases along with economic development. 


\section{Research scope and method}

The urban area Żydowce is part of the administrative unit Żydowce-Klucz of the Szczecin City, numbering about 2.5 thousand inhabitants and located next to the southern bypass, approximately $10 \mathrm{~km}$ from the downtown of Szczecin. The area is peripheral, sparsely populated, dominated by the single-family housing, and surrounded by riverside meadows and arable fields.

The survey was conducted between 15:00 and 19:00, on 5-7.05.2016 in the urban area Żydowce using the direct interview method, on a sample of 50 respondents. Most of them, as many as 47 were residents of the urban area Żydowce, and three no residents, which constituted only $6 \%$ of the total number of respondents. The study was attended by 25 women and 25 men. Persons from five age groups were surveyed: $22 \%$ each from the age groups $40-54,55-59$, and over $60,18 \%$ from the age group $15-24$; and $16 \%$ from the age group $25-39$. The duration of the interview was about five minutes. The survey results are representative for this urban area.

\section{Results}

\section{Social assessment of the quality of neighhourhood services}

The majority of respondents, as much as $62 \%$, believe that there is not enough neighbourhood services in the urban area Żydowce. According to $32 \%$ of respondents, the number of services is sufficient. Only $6 \%$ of the respondents did not have an opinion on this topic.

The general assessment of the quality of the services offered in the urban area Żydowce is of poor quality, as many as $44 \%$ of respondents expressed such an opinion. The largest group of respondents, for whom the quality of services is poor, is a group of men $-24 \%$. Women accounted for $20 \%$, of which half of the women came from the 15-24 age group. The lowest number of respondents to the poor quality of service assessment was given by women from the $60+$ age group (4\%).

$14 \%$ of respondents are of the opinion that the quality of the offered services is medium (of which women were $8 \%$ and men $6 \%$ ). Most people gave such a response from the 25-39 age group, mainly employed and one person with the status of a retired or pensioner.

The quality of services was rated good by $22 \%$ of respondents. For the most part, they were women, they accounted for $73 \%$ of this group. Most people who answered that the quality of services in this urban area is at a good level is included in the age group 60+. They were three women and one man, all with the status of a retired person or a pensioner.

Only $10 \%$ of respondents rate the quality of neighbourhood services at a very good level. Thus, claiming that there is no shortage of services on the urban area Żydowce. The largest number of people who responded so were $60+(6 \%) .10 \%$ ( $6 \%$ of women and $4 \%$ of men) of respondents said they have no opinion on the quality of services offered in the urban area Żydowce. In conclusion, it can be said that the positive assessment of neighbourhood service concerns older, retired residents, more women than men.

\section{Neighbourhood services that need improvement}

When asked "which services in the urban area Żydowce need improvement" respondents could indicate a maximum of five types of services. According to the survey results, the strong improvement requires: gastronomy and catering services (fast food restaurant, pizzeria, pub, café, ice cream parlor) and public transport (25\% each); 
sport and educational services (6\% each). Most people in the 15-24 age group (12\%) claimed that gastronomy and catering services need improvement. As far as the improvement of public transport services is concerned, the respondents from different age groups were of the opinion that it requires improvement, the three most-important groups of 10\% are: young men and women aged 15-24, employed people in the 54-59 age group, and retired or pensioners aged $60+$. Other services that need improvement include gastronomy and catering services (3\%), entertainment $(3 \%)$, medical care $(2 \%)$, and banking services $(2 \%)$. There was also a small demand for: repair, cosmetic, hairdressing, pharmacy and insurance services ( $1 \%$ each). However, $40 \%$ of respondents say that neighbourhood services do not need to be improved in the urban area Żydowce.

\section{Missing neighbourhood services}

In response to the question "What neighbourhood services are missing in the urban area Żydowce" respondents could indicate a maximum of five types of services. The respondents identified pharmacies and medical care ( $17 \%$ each) for the gastronomy and catering services most missing in the urban area Żydowce. Then they pointed to entertainment, services and sports ( $9 \%$ each). Fewer, respondents found that there is a lack of gastronomy and catering services (8\%) and hairdressing services $(6 \%)$ in the urban area. Next, the respondents indicated missing services of RTV-repair, and other repair services, culture and banking services ( $4 \%$ each). The least indications were the lack of construction and renovation services, dry cleaners and gas stations (1\% each). The most opinions on the lack of pharmacies were given in the $40-54$ age group (12\%). As far as medical care is concerned, the majority of opinions were expressed by people working in the 55-59 age group.

The lack of gastronomy and catering services in the urban area Żydowce is most worried by women from the 15-25 age group (14\%) and men from the 55-59 age group (8\%). Women from the 15-24 age group (8\%) complain about the lack of sports services. The respondents from the 55-59 age group most complain about the lack of gastronomy and catering services ( $8 \%$, of which: $4 \%$ women and $4 \%$ men). However, the respondents' opinions on the lack of hairdressing services were equally distributed in four age groups of $16 \%$ each.

There is also no RTV-repair service in the urban area. For $8 \%$ of men, from the age group 25-39 and 40-54, this is a service that is needed in this area. The largest number of votes for the lack of culture and banking services was given to men aged $55-59(8 \%)$. On the other hand, $16 \%$ of respondents claim that there is no shortage of neighbourhood services in the urban area Żydowce.

\section{Conclusions}

The use of direct interview method and the analysis of respondents' opinions made it possible to determine whether the taken hypotheses were confirmed in the research. The verification of the collected data shows that $62 \%$ of respondents believe that there is not an adequate number of services in the urban area Żydowce. The most missing services in this area include medical care, pharmacy and entertainment. The largest percentage of them is a group of employed people for whom the number of basic services offered on the neighbourhood is particularly important.

Further analysis of the respondents' answers confirms the second hypothesis, as $44 \%$ of respondents believe that their neighbourhood services quality is at a poor level, only $22 \%$. claims that the quality of services is good. $14 \%$ of respondents were in favor of the average quality rating. $10 \%$ of respondents said the quality was very good and $10 \%$ refrained from rating. 
Referring to the results of the study, we find the justification for the next hypothesis, which talks about the need of services improvement in the urban area Żydowce. The respondents most frequently asked for services requiring immediate improvement were gastronomy and catering services (44\%) and public transport (44\%).

The respondents identified pharmacies and medical care (17\% each) for the services most missing in the urban area Żydowce. Some of the respondents pointed to the lack of entertainment and sports services ( $9 \%$ each) and gastronomy and catering services (8\%).

The improvement of the quality and broadening of the offer of the neighbourhood services is conditioned by the level of purchasing power of the residents. Local authorities may, indeed, improve access by public transport to the to the nearest district center and to the downtown of Szczecin. Such project, however, may reduce the demand for these services in the urban area Żydowce.

\section{References}

American Marketing Association (2018). Dictionary. Retrieved from: https://www.ama.org/resources/Pages/Dictionary.aspx?dLetter=S. Barton, H., Grant, M., Guise, R. (2006). Shaping Neighbourhoods: For Local Health and Global Sustainability. London: Routledge.

Chmielewski, J. (2001). Teoria urbanistyki w projektowaniu i planowaniu miast. Warszawa: Oficyna Wydawnicza Politechniki Warszawskiej.

Hollins, B., Shinkins, S. (2006). Managing Service Operations: Design and Implementation. London: SAGE Publications.

Jakubowicz, E. (1993). Podstawy metodologiczne geografii usług. Wrocław: Wydawnictwo Uniwersytetu Wrocławskiego.

Kłosiński, A.K. (2011). Światowy rynek usług w początkach XXI wieku. Poznań: PWE.

Nowosielska, E. (1972). Przestrzenne zróżnicowanie poziomu rozwoju usług w Polsce. Teoretyczne i praktyczne uwarunkowania badań. Wrocław: Instytut Geografii i Rozwoju Regionalnego Uniwersytetu Wrocławskiego.

Payne, A. (1997). Marketing usług. Warszawa: PWE.

Rogoziński, L. (1993). Usługi rynkowe. Poznań: Wydawnictwo Akademii Ekonomicznej.

Cite this article as: Sypion-Dutkowska, N., Karwan, M. (2018). Social assessment of the neighbourhood services in the urban area Żydowce in Szczecin (Poland). European Journal of Service Management, 4 (28/2), 455-461. DOl: 10.18276/ejsm.2018.28/2-54. 